\title{
The 1990s in Japan: A Lost Decade*
}

\author{
Fumio Hayashi \\ University of Tokyo \\ E-mail: Hayashi@e.u-tokyo.ac.jp \\ Edward C. Prescott \\ University of Minnesota \\ Research Department, Federal Reserve Bank of Minneapolis, \\ Minneapolis, Minnesota 55480 \\ Telephone: $\quad 612.204 .5520$ \\ FAX: $\quad 612.204 .5515$ \\ E-mail: prescott@econ.umn.edu
}

Running Head: The 1990s: Japan's lost decade 


\begin{abstract}
This paper examines the Japanese economy in the 1990s, a decade of economic stagnation. We find that the problem is not a breakdown of the financial system, as corporations large and small were able to find financing for investments. There is no evidence of profitable investment opportunities not being exploited due to lack of access to capital markets. The problem then and still today, is a low productivity growth rate. Growth theory, treating TFP as exogenous, accounts well for the Japanese lost decade of growth. We think that research effort should be focused on what policy change will allow productivity to again grow rapidly. Journal of Economic Literature Classification Numbers: E2, E13, O4, O5,
\end{abstract}

Key words: growth model, TFP, Japan, workweek

*We thank Tim Kehoe, Nobu Kiyotaki, Ellen McGrattan and Lee Ohanian for helpful comments, and Sami Alpanda, Pedro Amaral, Igor Livshits, and Tatsuyoshi Okimoto for excellent research assistance and the Cabinet Office of the Japanese government, the United States National Science Foundation, and the College of Liberal Arts of the University of Minnesota for financial support. The views expressed herein are those of the authors. 


\section{INTRODUCTION}

The performance of the Japanese economy in the 1990s was less than stellar. The average annual growth rate of per capita GDP was 0.5 percent in the 1991-2000 period. The comparable figure for the United States was 2.6 percent. Japan in the last decade, after steady catch-up for 35 years, not only stopped catching up but lost ground relative to the industrial leader. The question is why.

A number of hypotheses have emerged: inadequate fiscal policy, the liquidity trap, depressed investment due to over-investment during the "bubble" period of the late 1980s and early 1990s, and problems with financial intermediation. These hypotheses, while possibly relevant for business cycles, do not seem capable of accounting for the chronic slump seen ever since the early 1990s. This paper offers a new account of the "lost decade" based on the neoclassical growth model.

Two developments are important for the Japanese economy in the 1990s. First and most important is the fall in the growth rate of total factor productivity (TFP). This had the consequence of reducing the slope of the steady-state growth path and increasing the steady-state capital-output ratio. If this were the only development, investment share and labor supply would decrease to their new lower steady-state values during the transition. But, the drop in the rate of productivity growth alone cannot account for the near-zero output growth in the 1990s.

The second development is the reduction of the workweek length (average hours worked per week) from 44 hours to 40 hours between 1988 and 1993, brought about by the 1988 revision of the Labor Standards Law. In the most standard growth model, where aggregate hours (average hours worked times employment) enter the utility function of the stand-in consumer, a decline in workweek length does not affect the steady-state growth path because the decline is offset by an increase in employment. However, in our specification of the growth model, the workweek length and employment enter the utility function separately, so that a shortening of the workweek shifts the level of the steady-state growth path down. If the only change were a 
reduction in workweek length, the economy would converge to a lower steady-state growth path subsequent to the reduction in the workweek length.

We determine the consequence of these two factors for the behavior of the Japanese economy in the 1990s. To do this we calibrate our growth model to pre-1990 data and use the model to predict the path of the Japanese economy in the 1990s, treating TFP as exogenous and treating the workweek length as endogenous subsequent to 1993. The lost decade of growth is what the model predicts. Also predicted is the increase in the capital-output ratio and the fall in the return on capital that occurred through the 1990s. The only puzzle is why the TFP growth was so low subsequent to 1991. We discuss possible reasons for this decline in the concluding section of the paper.

In Section 2, we start with a brief catalogue of some of the facts about the lost decade. We then proceed to examine the Japanese economy through the perspective of growth theory in Section 3. We use this model economy to predict what will happen in the 1990s and beyond, taking the paths of productive efficiency, workweek lengths, capital tax rate, and the output share of government purchases as exogenous.

Growth theory gives no role to frictions in financial intermediation. To many this may appear a serious omission. It is natural to suspect that the collapse of bank loans that took place throughout the 1990s must have something to do with the output slump in the same decade. There is an emerging literature about Japan that asks (a) whether the decline in bank loans was a "credit crunch" - namely, a decline due to supply factors (such as the BIS capital ratio imposed on banks), and (b) if so, whether it depressed output by constraining investment. In Section 4 of the

\footnotetext{
${ }^{1}$ Kwon (1998) and Bayoumi (1999), using VAR analysis, concluded that fluctuations in asset prices affected output through bank lending. Ogawa and Suzuki (1998) find evidence from panel data on large Japanese firms that the price of land as collateral affected investment demand. Sasaki (2000) reports from micro data on Japanese banks that lending by "city" banks (large
} 
paper, we present evidence from various sources that the answer to the first question is probably yes, but the answer to the second question is no. That is, despite the collapse of bank loans, firms found ways to finance investment. This justifies our neglect of financial factors in accounting for the lost decade. Section 5 contains concluding remarks.

\section{THE JAPANESE ECONOMY 1984-2000}

We begin with an examination of the NIA (National Income Accounts) data for the 1984-2000 period and report the facts that are most germane to real growth theory, which abstracts from monetary and financial factors. In the next section, we will determine the importance of the TFP behavior and the reduction in the workweek length on the behavior of the Japanese economy in the 1990s.

\section{Poor Performance in the 1990s}

Figure 1 documents Japan's prolonged slump in the 1990s. The figure graphs the Japanese real GNP per adult (aged 20-69), detrended at 2 percent (which has been the long-run growth rate for the leader country over the past century) and normalized to 100 for $1990^{2}$ The performance of the Japanese economy was very good in the 1980s, growing at a much higher rate than the benchmark 2 percent, and looking as if poised to catch up with the United States. However, this

Japanese banks) was constrained by the BIS capital ratio requirement. Woo (1999) finds support for the BIS-induced capital crunch only for 1997. Ogawa and Kitasaka (1998, chapter 4) assert that the decline in asset prices shifted both the demand curve and supply curve of bank loans, which resulted in a fall in investment without noticeable change in lending rates. Motonishi and Yoshikawa (1999), while generally disagreeing with the view that investment was constrained by bank lending, find evidence for a credit crunch for 1997 and 1998.

${ }^{2}$ Our procedure for constructing data underlying this and other figures and tables is explained in the Data Appendix. 
trend reversed itself subsequent to 1991, and by 2000 the Japanese per adult GNP is less than 90 percent of what it would have been had it kept growing at 2 percent since 1991. Part of this slowdown is due to a decline in TFP growth. Over the 1983-1991 period, TFP grew at a more than respectable rate of 2.4 percent. It fell to an average of 0.2 percent for 1991-2000.

\section{Figure 1: Detrended real GNP per working-age person $(1990=100)$}

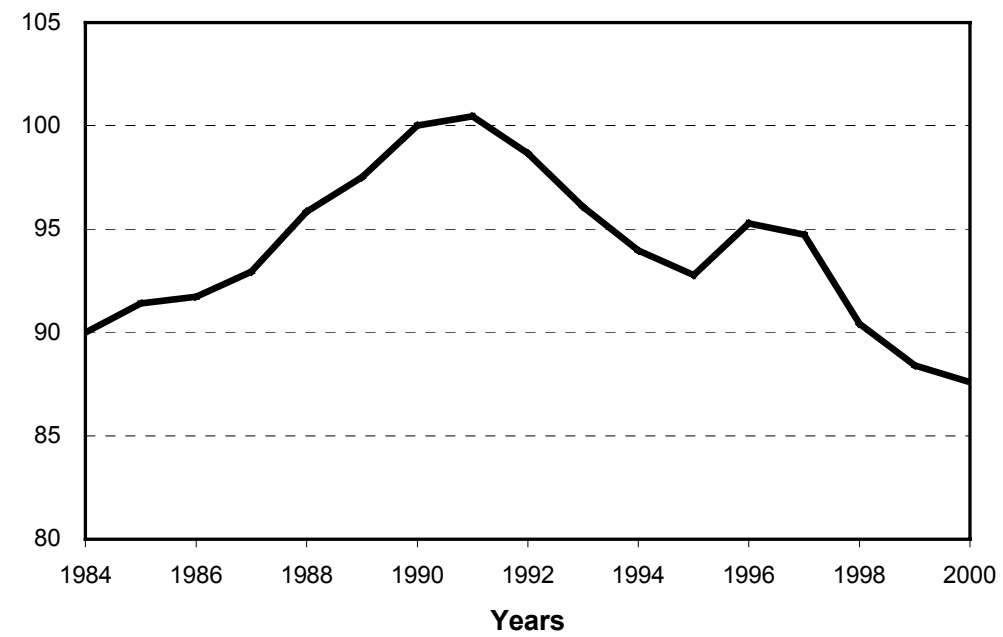

\section{Workweek Falls in the 1988-93 Period}

An important policy change occurred at the end of the 1980s. The workweek length declined from 44 hours in 1988 to 40 hours in 1993, as depicted in Figure 2. This decline was by government fiat. For the first time in 40 years, there was a major revision of the Labor Standards Law in 1988 , which stipulated a gradual reduction in the statutory workweek ${ }^{4}$ from 48 hours

\footnotetext{
${ }^{3}$ The TFP is calculated as $Y_{t} /\left(K_{t}{ }^{\theta} L_{t}{ }^{1-\theta}\right)$ where the capital share $\theta$ is set to $0.362, Y_{t}$ is GNP, $K_{t}$ is the nongovernment capital stock, $L_{t}$ is aggregate hours worked. The average annual TFP growth rate over 1983-1991 is $\left(A_{1991} / A_{1993}\right)^{1 /(1991-1983)}-1$, which is approximately equal to the average of the annual growth rates between 1984 and 1991.

${ }^{4}$ The employer must pay a higher wage rate to have the employee work longer than this statutory
} 
down to 40 hours (six down to five workdays per week), to be phased in over several years. The number of national holidays increased by three during this period. Government offices were closed on Saturdays every other week beginning in 1989, and since 1992 have been closed every Saturday. Financial institutions have been closed every Saturday since 1989. A new temporary law was introduced in 1992 to bring about further reduction in hours worked. The 1998 revision of the Labor Standards Law added one day to paid vacation. It appears that the government's drive to reduce workweek had a lot of public support, judging from newspaper accounts.

\section{Figure 2: Length of workweek}

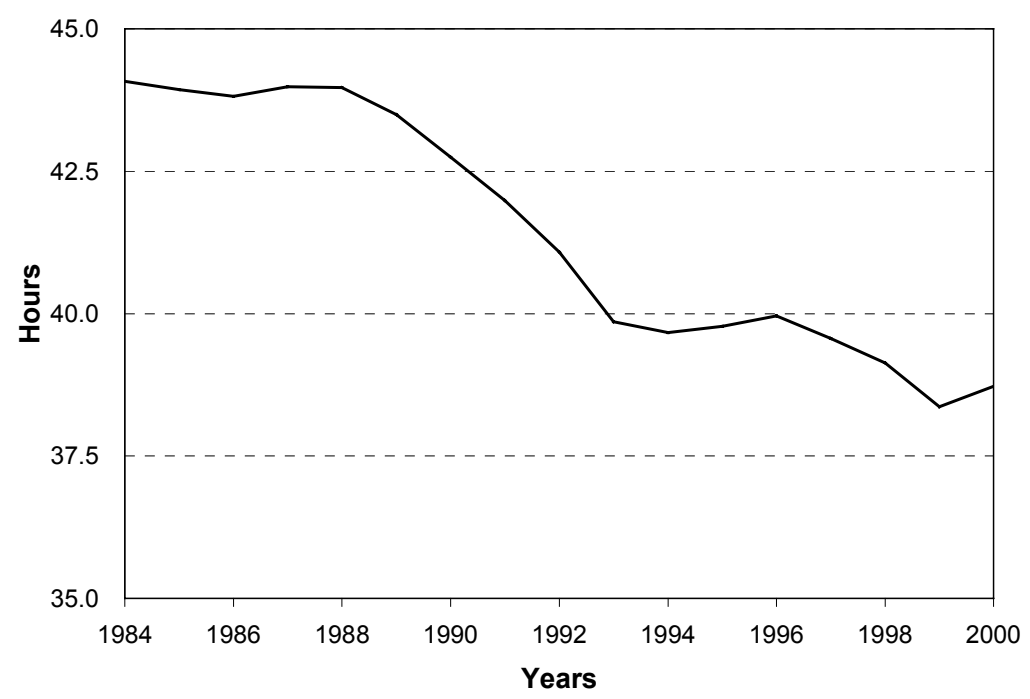

\section{Capital Deepens as the Rate of Return Declines in the 1990s}

Figure 3 plots the nongovernment capital-output ratio. An accounting convention we follow throughout the paper is that all government purchases are expensed (i.e., treated as consumption) and that the current account balance (the sum of net exports and net factor income from abroad) is included as investment. Therefore, the capital stock excludes government capital but includes claims on the rest of the world (foreign capital).

limit. 


\section{Figure 3: Capital-output ratio}

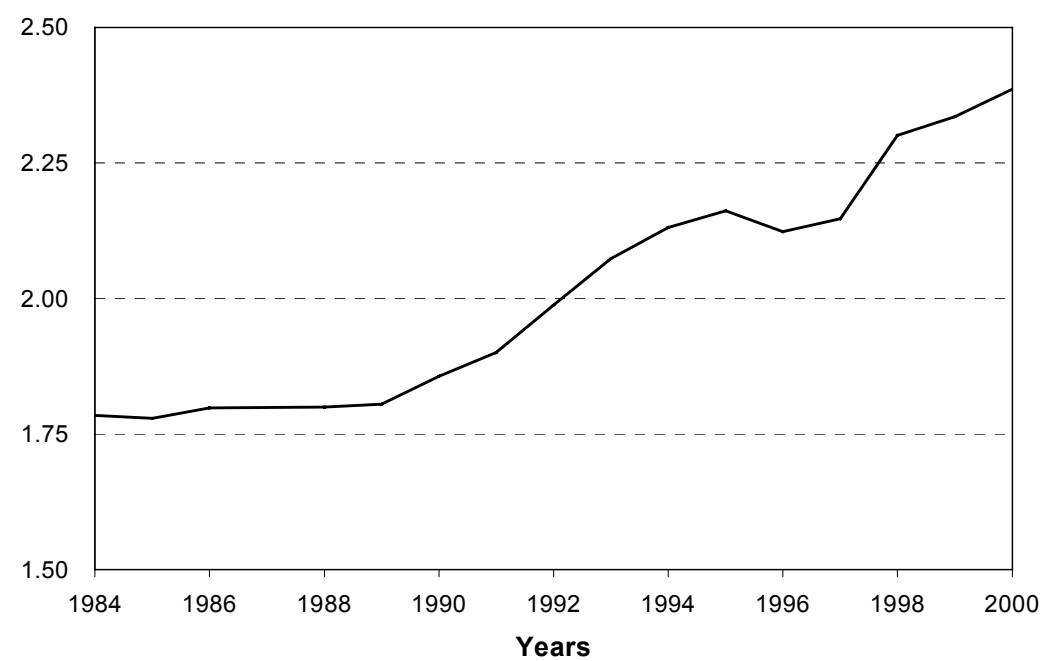

Following theory, we include inventory stocks as part of the capital stock. Looking at Figure 3, we note that there was a significant capital deepening, with the capital-output ratio increasing by nearly 30 percent, from 1.86 at the beginning of 1990 to 2.39 in 2000 . (If the capital stock excludes foreign capital, the ratio increases from 1.67 in 1990 to 1.98 in 2000.) Associated with this capital deepening, there was a decline in the after-tax (and net) return on capital, depicted in Figure 4, from 6.1 percent in the late 1980 s to 4.2 percent in the late $1990 \mathrm{~s}$.

Figure 4: After-tax rate of return

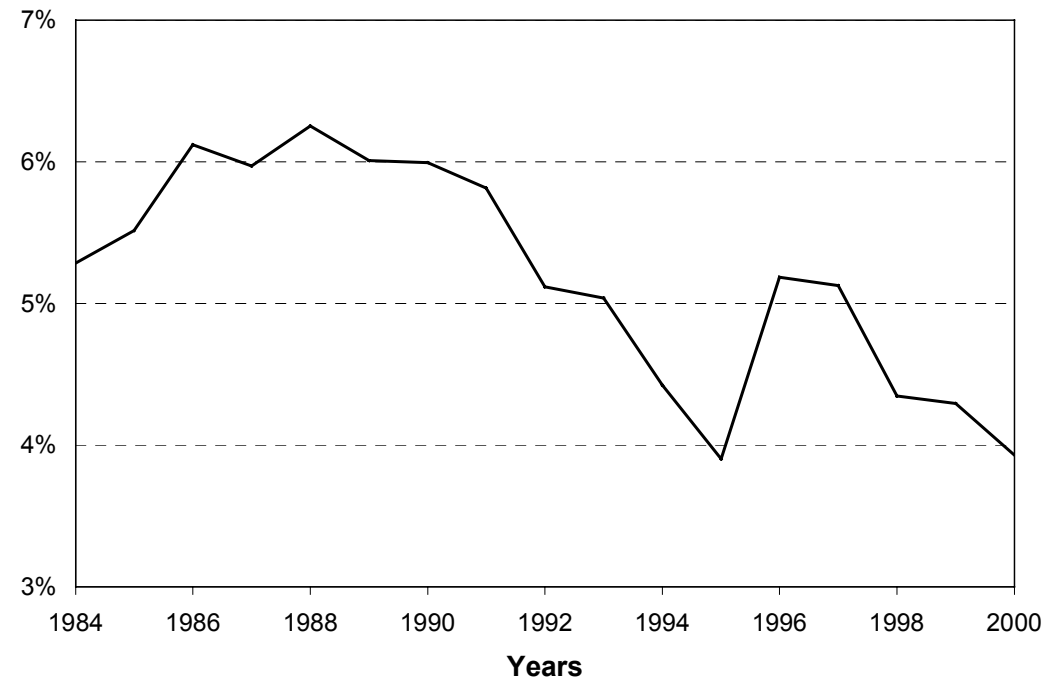


Both these rate of return figures are too high because part of the return includes the return on land. To get a better idea of the levels of return as opposed to just the change in returns, we examine returns in the non-land intensive sectors, namely the corporate and foreign sectors. The decline in after-tax profits divided by capital stocks in these sectors is from 5.3 percent to 2.1 percent. This leads us to the assessment that the after-tax return on capital declined over three percentage points between 1990 and 2000: from over 5 percent to about 2 percent.

\section{Government Share Increases and Investment Share Decreases in the 1990s}

Figure 5 shows that the composition of output changed in the 1990s. The government's share of output increased from an average share of 13.7 percent in the $1984-90$ period to 15.2 percent in the 1994-2000 period. Another change is the decline in private investment share from 27.6 percent to 24.3 percent in these periods. Most of the decline in investment occurred in the domestic investment component, not in the current account: the output share of domestic investment declined by 3 percentage points, from 24.6 percent to 21.7 percent. The decline in the late 1990s is rather substantial.

Figure 5: Government purchases and investment as a share of output

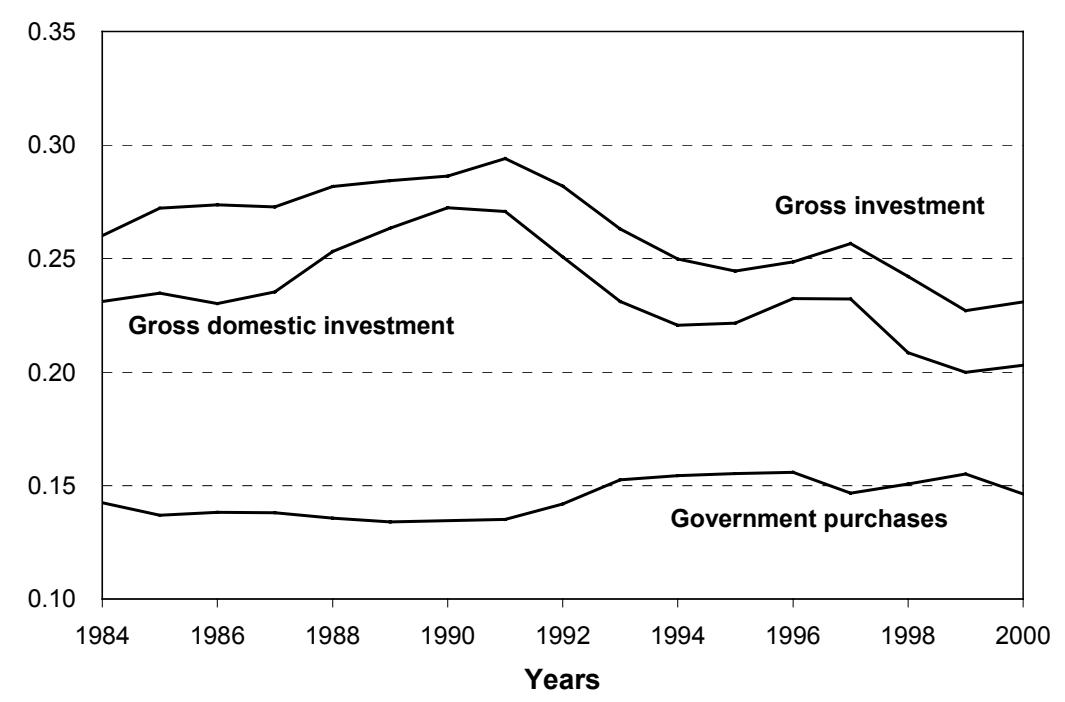




\section{JAPANESE ECONOMY FROM THE GROWTH THEORY PERSPECTIVE}

In using growth theory to view the Japanese economy in the 1990s, we are using a theory that students of business cycles use to study business cycles and students of public finance use to evaluate tax policies. The standard growth model, however, must be modified in one important way - to take into account the consequences of a policy change that led to a reduction in the average workweek in Japan in the 1988-93 period. Taking as given the fall in the workweek length, the fall in productivity growth, and the increase in the output share of government purchases in the 1990s, we use the theory to predict the path of the Japanese economy after 1990.

\subsection{The Growth Model}

\section{Technology}

The aggregate production function is

$$
Y=A K^{\theta}(h E)^{1-\theta}
$$

where $Y$ is aggregate output, $A$ is TFP, $K$ is aggregate capital, $E$ is aggregate employment, and $h$ is hours per employee.

\section{Growth Accounting}

Having specified the aggregate production function, we can go back to the data on the Japanese economy and perform growth accounting. Our growth accounting, involving the capital-output ratio instead of the capital stock, is equivalent to, but differs in appearance from, the usual growth accounting. Let $N$ be the working-age population and define:

$$
y \equiv Y / N, e \equiv E / N, x \equiv K / Y \text {. }
$$

Using these definitions on (1) and by simple algebra, we obtain

$$
y=A^{1 /(1-\theta)} h \text { e } x^{\theta /(1-\theta)}
$$

That is, output per adult $y$ can be decomposed into four factors: the TFP factor $A^{1 /(1-\theta)}$, the 
workweek factor $h$, the employment rate factor $e$, and the capital intensity factor $x^{\theta /(1-\theta)}$. Our growth accounting is convenient because the growth rate in the TFP factor coincides with the trend growth rate of output per adult, namely the growth rate when hours worked $h$, the employment rate $e$, and the capital output ratio $x(=K / Y)$ are constant.

Table I reports the growth rate of each of these factors for various subperiods since 1960. The capital share parameter $\theta$ is set at 0.362 (see our discussion below on calibration). The contribution of TFP growth between 1983-1991 and 1991-2000 accounts for nearly all the decline in the growth in output per working-age-person. In spite of the low TFP growth in the 1973-83 period, output per adult increased at 2.2 percent. The reason that growth in output per adult was higher in the 1973-83 period than in the 1991-2000 period is that in the earlier period there was significantly more capital deepening and a smaller reduction in the labor input per working-ageperson.

Table I: Accounting for Japanese Growth per Person Aged 20-69

\begin{tabular}{cccccc}
\hline \multirow{2}{*}{ Period } & Growth rate & \multicolumn{4}{c}{ Factors } \\
\cline { 3 - 6 } & & $\begin{array}{c}\text { TFP } \\
\text { factor }\end{array}$ & $\begin{array}{c}\text { Capital } \\
\text { intensity }\end{array}$ & $\begin{array}{c}\text { Workweek } \\
\text { length }\end{array}$ & $\begin{array}{c}\text { Employment } \\
\text { rate }\end{array}$ \\
\hline $1960-1973$ & $7.2 \%$ & $6.5 \%$ & $2.3 \%$ & $-0.8 \%$ & $-0.7 \%$ \\
$1973-1983$ & $2.2 \%$ & $0.8 \%$ & $2.1 \%$ & $-0.4 \%$ & $-0.3 \%$ \\
$1983-1991$ & $3.6 \%$ & $3.7 \%$ & $0.2 \%$ & $-0.5 \%$ & $0.1 \%$ \\
$1991-2000$ & $0.5 \%$ & $0.3 \%$ & $1.4 \%$ & $-0.9 \%$ & $-0.4 \%$ \\
\hline
\end{tabular}

\section{Households}

We model workweek length $h$ as being exogenous prior to 1993 and endogenous thereafter.

\footnotetext{
${ }^{5}$ The average annual TFP growth rate over 1983-1991, for example, is calculated as $\left(A_{1991} / A_{1993}\right)^{1 /(1991-1983)}-1$.
} 
Following Hansen (1985) and Rogerson (1988), labor is indivisible so that a person either works $h$ hours or does not work at all. There is a stand-in household with $N_{t}$ working-age members at date $t$. The size of the household evolves over time exogenously. Measure $E_{t}$ of the household members work a workweek of length $h_{t}$. The stand-in household utility function is

$$
\sum_{t=0}^{\infty} \beta^{t} N_{t} U\left(c_{t}, h_{t}, e_{t}\right) \text { with } U\left(c_{t}, h_{t}, e_{t}\right)=\log c_{t}-g\left(h_{t}\right) e_{t}
$$

where $e_{t} \equiv E_{t} / N_{t}$ is the fraction of household members that work and $c_{t} \equiv C_{t} / N_{t}$ is per member consumption.

As policy decreased the workweek length over time, the disutility of working depends on $h$. This disutility function is approximated in the neighborhood of $h=40$ by a linear function

$$
g(h)=\alpha(1+(h-40) / 40)
$$

For this function, if not constrained, the workweek length chosen by the household is 40 hours. This follows from household first-order conditions (11) and (12) below.

To incorporate taxes, we assume that the only distorting tax is a proportional tax on capital income at rate $\tau$. We could also incorporate a proportional tax on labor income. Provided that the rate is constant over time, the labor tax does not affect any of our results. This is because the labor tax, if included in the model, will be fully offset by a change in the calibrated value of $\alpha$ (see the consumption-leisure first-order condition (11) and (12) below to see this point more clearly). Since 1984 there has been no major tax reform affecting income taxes, it is reasonable to assume that the average marginal tax rate on labor income (i.e., the marginal tax rates averaged over different tax brackets) has been constant. We treat all other taxes as a lump-sum tax. The resulting period-budget constraint of the household, which owns the capital and rents it to the business sector, is

$$
C_{t}+X_{t} \leq w_{t} h_{t} E_{t}+r_{t} K_{t}-\tau\left(r_{t}-\delta\right) K_{t}-\pi_{t} .
$$


Here $w_{t}$ represents the real wage, $\pi_{t}$ the lump sum taxes and $r_{t}$ is the rental rate of capital.

The after-tax interest rate equals

$$
i_{t}=(1-\tau)\left(r_{t+1}-\delta\right)
$$

The reason that we include a capital income tax is that a key variable in our analysis is the aftertax return on capital and this return is taxed at a high rate in Japan, even higher than in the United States.

\section{Closing the Model}

Aggregate output $Y_{t}$ is divided between consumption $C_{t}$, government purchases of goods and services $G_{t}$, and investment $X_{t}$ 苗 Thus

$$
C_{t}+X_{t}+G_{t}=Y_{t}
$$

Capital depreciates geometrically, so

$$
K_{t+1}=(1-\delta) K_{t}+X_{t}
$$

The government budget constraint is implied by the household budget constraint (6) and the resource constraint (8). By treating the capital tax income rate $\tau$ as a policy parameter, we are assuming that changes in government purchases are financed by changes in the lump-sum tax $\pi_{t}$. Thus, Ricardian Equivalence holds in our model.

\subsection{Calibration}

We calibrate the model to the Japanese economy during 1984-89. There are five model parameters: $\theta$ (capital share in production), $\delta$ (depreciation rate), $\beta$ (discounting factor), $\alpha$

\footnotetext{
${ }^{6}$ Recall that in our accounting framework government investment is included in $G$ and that investment consists of domestic private investment and the current account surplus. Hence (8) holds with $Y_{t}$ representing GNP.
} 
(disutility of working), and $\tau$ (capital income tax rate). The data on the Japanese economy that go into the following calibration (such as data on taxes on capital income) are described in the Data Appendix.

$\theta$ The share parameter is determined in the usual way, as the sample average over the period 1984-89 of the capital income share in GNP.

$\delta$ This is set equal to the sample average over the $1984-89$ period of the ratio of depreciation to the beginning-of-the-year capital stock.

$\tau$ This is set equal to the average rate in the 1984-89 period.

$\beta$ The discount factor is obtained from the intertemporal equilibrium condition.

$$
\frac{U_{c_{t}}}{U_{c_{t+1}}}=\frac{c_{t+1}}{c_{t}}=\beta\left[1+(1-\tau)\left(r_{t+1}-\delta\right)\right],
$$

where $U_{c_{t}}$ is the marginal utility of consumption for the period-utility function given in (5) and $r_{t+1}$ is the marginal productivity of capital. We average this equation over the 1984-89 period and solve for $\beta$.

$\alpha \quad$ The disutility of work parameter $\alpha$ is obtained from the household maximization conditions for $e$ and $h$ :

$$
\begin{aligned}
& c_{t} g\left(h_{t}\right)=w_{t} h_{t} \\
& c_{t} g^{\prime}\left(h_{t}\right) E_{t}=w_{t} E_{t} .
\end{aligned}
$$

Equation (11) holds whether or not $h$ is constrained and is the equation used to calibrate $\alpha$. The calibrated value is the average value for the period 1993-2000, the years that the workweek was not constrained. 
The calibrated parameter values are displayed in Table II.

Table II: Calibration

\begin{tabular}{cc}
\hline Parameter & Value \\
\hline$\theta$ & 0.362 \\
$\delta$ & 0.089 \\
$\beta$ & 0.976 \\
$\alpha$ & 1.373 \\
$\tau$ & 0.480 \\
\hline
\end{tabular}

\subsection{Findings}

We have calibrated the growth model to the Japanese economy for the 1984-89 period. We now use this calibrated model to predict what will happen in the 1990s and beyond.

\section{Initial Conditions and Exogenous Variables}

The simulation from year 1990 takes the actual capital stock in 1990 as the initial condition. The exogenous variables are $\left(A_{t}, N_{t}, \psi_{t}\right)$, where $\psi_{t}$ is $G_{t} / Y_{t}$, the GNP share of government purchases. We also take hours worked $h_{t}$ to be exogenous for $t=1990-1992$. We need to specify the time path of those exogenous variables from 1990 on. For the 1990s $(t=1990,1991, \ldots$, 2000), we use their actual values. For $t=2001,2002, \ldots$, we assume the following. The TFP factor $A_{t}^{1 /(1-\theta)}$ is set to its $1991-2000$ average of 0.29 percent. We assume no population growth so that $N_{t}$ is set to its 2000 value. The government's share $\psi_{t}$ is set equal to its value in the 1999-2000 period of 15 percent.

Our simulation is deterministic. The issue of what TFP growth expectations to assign to the economic agents is problematic. We do not maintain that the decline in the growth rate of the 
TFP factor in the 1990s was forecasted in 1990, even though we treat it as if it were. The justification is that a deterministic model is simple and suffices for answering our question of why the 1990s was a lost decade for the Japanese economy. If expectations had been modeled in any not unreasonable way, the key predictions of the model would be essentially the same. In particular, the magnitudes of the increase in the capital-output ratio and the fall in the return on capital would be the same.

Figures 6-8 report the behavior of the model and actual outcomes. As can be seen from Figure 6, the actual output in the $1990-2000$ period is close to the predictions of our calibrated model. Theory with TFP exogenous predicts Japan's chronic slump in the 1990s.

\section{Figure. 6: Detrended real GNP per working-age person $(1990=100$}

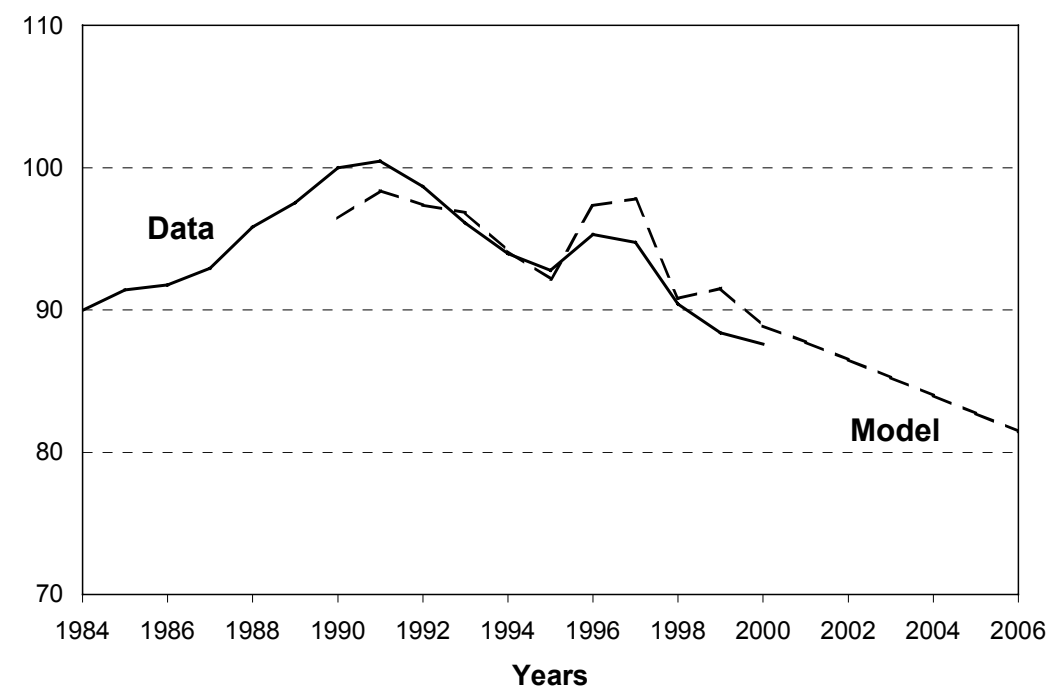

The observed deepening of capital and the decline in the rate of return, noted in Section 2 and reproduced in Figures 7 and 8, are also predicted by the model. 


\section{Figure7: Capital-output ratio}

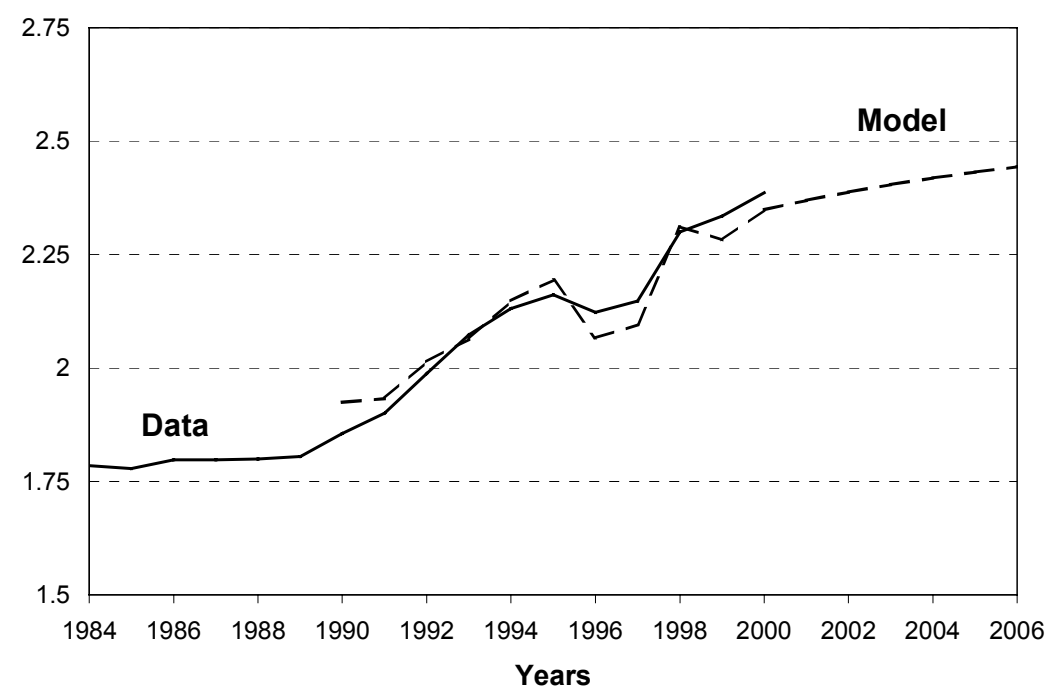

The capital-output ratio rises as output growth falls because the capital-output ratio associated with a lower productivity growth is higher. This can easily be seen from equation (10). In the new steady state with lower productivity growth, the consumption growth rate is lower, which means that the rate of return from capital is lower. Under diminishing returns to capital, the capitaloutput ratio must therefore be higher.

Figure 8: After-tax rate of return

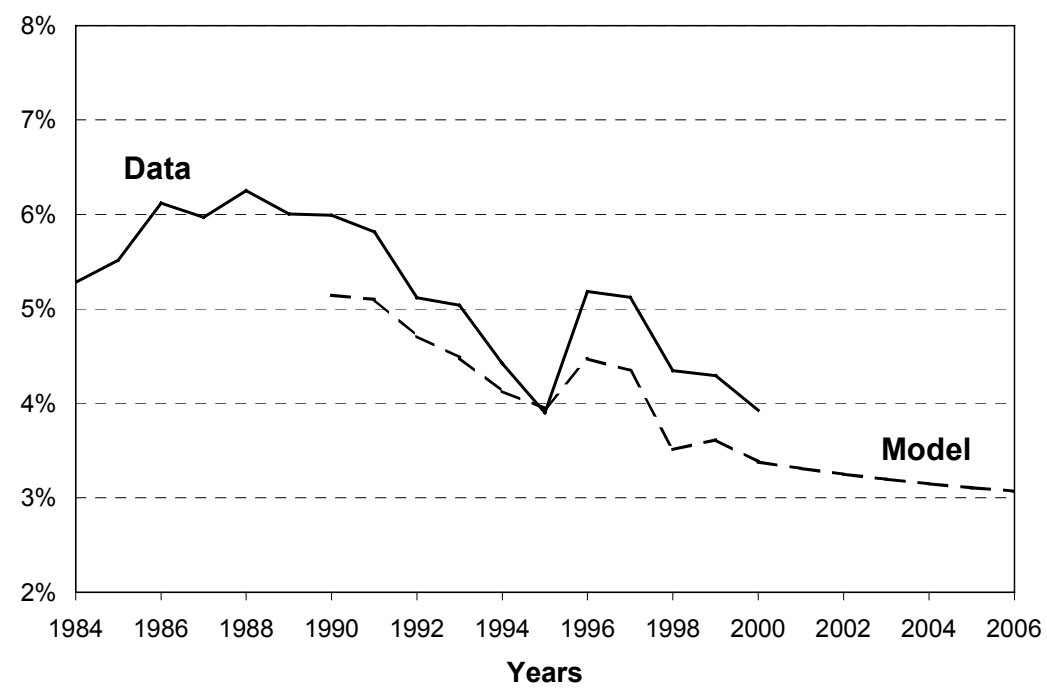


The difference in the precise paths of the model and actual path of the capital-output ratio is not bothersome given the model's assumption that the future path of the TFP factor was predicted perfectly by the economic agents when in fact it is not. Neither is the discrepancy between model and actual returns in Figure 8 bothersome. This is as expected given actual returns include return on land as well as capital as discussed in Section 2.

The model's predictions for the 1990s are not sensitive to the values of the exogenous variables for the years beyond 2000. The predictions for the first decade of the twenty-first century, however, depend crucially on the values of the exogenous parameters for that decade. The most important variable is TFP. If the TFP growth rate increases to the historical norm of the industrial leader, Japan will not fall further behind the leader — rather, it will maintain its position relative to the industrial leader. If on the other hand, TFP growth is more rapid than the leader, Japan will catch back up. We make no forecasts as to what TFP growth will be, and emphasize that this forecast is conditional on the TFP growth rate remaining low.

Assuming that TFP growth remains low, Japan cannot rely on capital deepening for growth in per-working-age-person output as it did in the past, as the Japanese capital stock is near its steady-state value. On the other hand, decreases in the labor input (aggregate hours) will not reduce growth as it has in the past, because, under our specification (5), average hours worked $h$ will not magnify the disutility of aggregate hours worked when it is less than 40 hours. The Japanese people now work approximately the same number of hours as do Americans. If TFP growth again becomes as rapid as it was in the 1983-1991 period, the labor input will increase and this will have a positive steady-state level effect on output.

\section{Was Investment Constrained?}

An important alternative hypothesis about Japan's lost decade is what we call the "credit crunch" 
hypothesis. It holds that, for one reason or another, there is a limit on the amount a firm can borrow. If bank loans and other means of investment finance are not perfect substitutes, an exogenous decrease in the loan limit constrains investment and hence depresses output. ${ }^{\text {Th }}$ This hypothesis is becoming an accepted view even among academics. It has an appeal because the collapse of bank loans and the output slump occurred in the same period (the 1990s) and because the collapse of bank loans seems exogenous, taking place when the BIS capital ratio is said to be binding for many Japanese banks. In this section, we confront this "credit crunch" hypothesis with data from various sources.

\subsection{Evidence from the National Accounts}

As mentioned at the end of Section 2, the output share of domestic investment declined substantially in the 1990s. If this decline is due to reduced bank lending, we should see much of the decline in investment by nonfinancial corporations. The Japanese National Accounts has a flow-of-funds account (called the capital transactions account) for the nonfinancial corporate sector that allows us to examine sources of investment finance. The cash flow identity for firms states that

investment (excluding inventory investment)

$=(\mathrm{a})$ net increase in bank loans

$+(b)$ net sales of land

$+(\text { c) gross corporate saving (i.e., retention plus accounting depreciation })^{8}$

$+(d)$ net increase in other liabilities

\footnotetext{
${ }^{7}$ See, e.g., Kashyap and Stein (1994) for a fuller statement of the hypothesis.

${ }^{8}$ Since investment excludes inventory investment here, retention is defined as sales (rather than output) minus the sum of costs, net interest payments, corporate taxes, and dividends.
} 
(i.e., new issues in shares and corporate bonds plus net decrease in financial assets).

The capital transactions account in the Japanese National Accounts allows one to calculate items (a)-(d) above for the nonfinancial corporate sector.

Figure 9 shows investment (excluding inventory investment) and item (a) (net increase in bank loan balances) as ratios to GNP. (The difference between the two, of course, is the sum of items (b), (c), and (d).)

\footnotetext{
${ }^{9}$ The nonfinancial corporate sector in the Japanese National Accounts includes public nonfinancial corporations (such as corporations managing subways and airports), which get funding from the Postal Saving System (a huge government bank) through a multitude of government accounts collectively called the Fiscal Investment and Loan Program (FILP). It is not possible to carry out the flow-of-funds analysis for private nonfinancial corporations by excluding public corporations, because the Japanese National Accounts do not include a separate capital transactions account for this sector. However, the income-expenditure account for this sector, which is available from the National Accounts, indicates that public nonfinancial corporations are a minor part, less than 10 percent of the nonfinancial corporate sector in terms of income (defined as operating surplus plus property income). Since the nonfinancial corporate sector is the object of our analysis here, the privatization of two large public corporations, Japan Railway and NTT (Nippon Telegraph and Telephone), does not have to be taken into account in our analysis.
} 


\section{Figure 9: Collapse of bank loans: nonfinancial corporate sector}

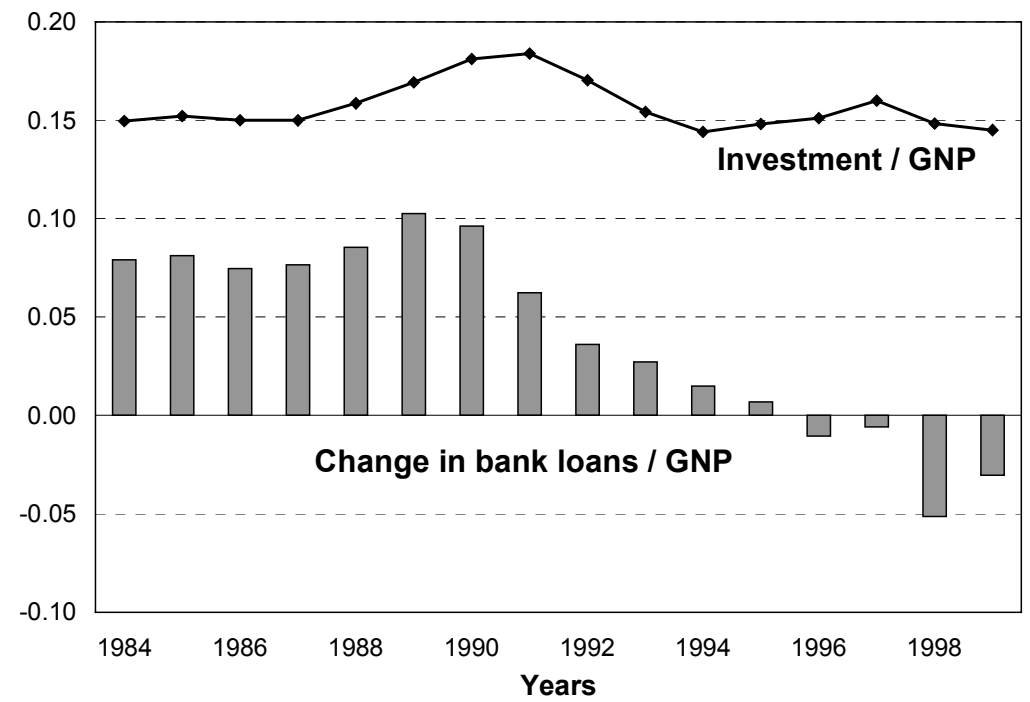

There are two things to observe. First, the dive in the output share of domestic investment, shown in Figure 5, did not occur in the nonfinancial corporate sector. The output share of investment by nonfinancial corporations remained at 15 percent, except for the "bubble" period of the late 1980s and early 1990s when the share was higher. Second, investment held up despite the collapse of bank loans in the $1990 \mathrm{~s} \frac{10}{10}$ That is, other sources of funds replaced bank loans to finance the robust investment by nonfinancial corporations in the $1990 \mathrm{~s}$. To corroborate on this second point, Table III shows how the sources of investment finance changed from 198488 to 1993-99 (thus excluding the "bubble" period). In the 1980s, bank loans and gross corporate saving financed not only investment but also purchases of land (see the negative entry for "sale of land" in the Table) and a buildup of financial assets (see the negative entry for "net increase in other liabilities"). In the 1990s, firms drew down the land and financial assets that had been built up during the 80 s to support investment. These observations are inconsistent with the "credit

\footnotetext{
${ }^{10}$ Bank loans here include loans made by public financial institutions. If loans from public financial institutions are not included, the decline in bank lending in the 1990s is more pronounced.
} 
crunch" hypothesis.

Table III: Sources of Investment Finance for Nonfinancial Corporations

\begin{tabular}{lcc}
\hline Sources of fund as & & \\
fraction of investment & $1984-88$ & $1993-1999$ \\
\hline (a) Bank loans & $52.2 \%$ & $-4.8 \%$ \\
(b) Sale of land & $-6.9 \%$ & $5.7 \%$ \\
(c) Gross savings & $79.2 \%$ & $88.1 \%$ \\
(d) Net increase in other & $-24.5 \%$ & $11.0 \%$ \\
\hline liabilities & $100 \%$ & $100 \%$ \\
\hline
\end{tabular}

\subsection{Evidence from Survey Data on Private Nonfinancial Corporations}

The preceding discussion, based on the National Accounts data, ignores distributional aspects. For example, large firms may not have been constrained while small ones were. As is well known (see, e.g., Hoshi and Kashyap (1999)), as a result of the liberalization of capital markets, large Japanese firms scaled back their bank borrowing and started to rely more heavily on open-market funding, and the shift away from bank loans is complete by 1990. It is also well known that for small firms, essentially the only source of external funding is still bank loans. Therefore, if investment is constrained for some firms, those firms must be small firms. How did the collapse of bank loans affect small firms?

The most comprehensive survey of private nonfinancial corporations (a subset of the nonfinancial corporate sector examined above) in Japan is a survey by the Ministry of Finance (MOF) 1 From annual reports of this survey published by the MOF, sample averages of various

\footnotetext{
${ }^{11}$ See the Data Appendix for more details on this MOF survey.
} 
income and balance sheet variables for "small" firms (whose paid-in capital is less than 1 billion yen) can be obtained for fiscal years (a Japanese fiscal year is from April of the year to March of the next year). Figure 10 is the small-firm version of Figure 9. The difference between investment and bank loans in the 1980s is much smaller in Figure 10 than in Figure 9, underscoring the importance of bank loans for small firms. In the 1990s, however, as in Figure 9, investment held firm in spite of the collapse of bank loans. The sources of investment finance for small firms are shown in Table IV. It is not meaningful in the MOF survey to distinguish between items (c) (gross saving) and (d) (net increase in liabilities other than bank loans) in the cash-flow identity (13). For example, suppose the firm reports hitherto unrealized capital gains on financial asset holdings by selling those assets and then immediately buying them back. This operation increases (c) and decreases (d) by the same amount. Therefore, in Table IV, items (c) and (d) are

Figure 10: Investment finance: small firms

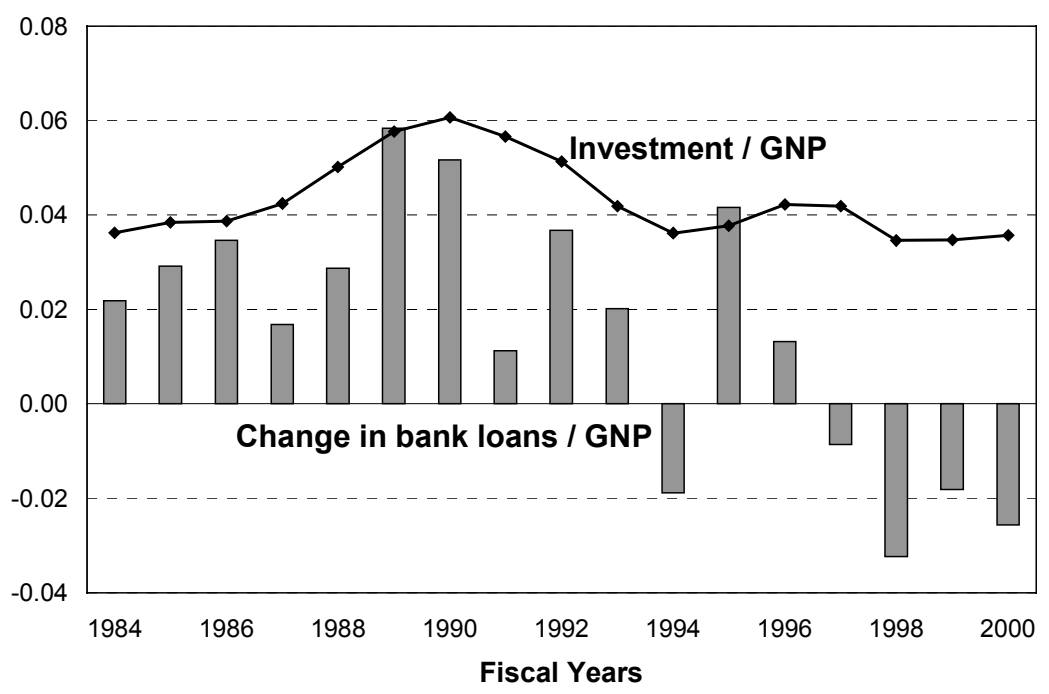

bundled into a single item called "other." The Table shows that small firms, despite the collapse of bank loans, continued to increase land holdings in the 1990s. That is, gross corporate saving and net decreases in financial assets combined were enough to finance not only the robust level of investment but also land purchases -- as all the while the loan balance was being reduced. 
As just noted, it is not possible to tell from the MOF survey which component -- saving or a running down of assets -- contributed more. It is, however, instructive to examine the evolution of a

\section{Table IV: Sources of Investment Finance for Small Nonfinancial Corporations}

\begin{tabular}{ccc}
\hline $\begin{array}{l}\text { Sources of fund as } \\
\text { fraction of investment }\end{array}$ & $\begin{array}{c}\text { Fiscal year } \\
1984-88\end{array}$ & $\begin{array}{c}\text { Fiscal year } \\
1993-2000\end{array}$ \\
\hline (a) Bank loans & $64.5 \%$ & $-12.6 \%$ \\
(b) Sale of land & $-18.3 \%$ & $-20.8 \%$ \\
(c) + (d) other & $53.8 \%$ & $133.4 \%$ \\
\hline Total & $100 \%$ & $100 \%$ \\
\hline
\end{tabular}

component of financial assets whose reported value cannot be distorted by inclusion of unrealized capital gains. Figure 11 graphs the ratio of cash and deposits to the (book value of) capital stock. First of all, the ratio is huge. The ratio for the nonfinancial corporate sector as a whole in the Japanese National Accounts is about 0.4.

\section{Figure 11: Ratio of cash plus deposits to stock capital: small firms}

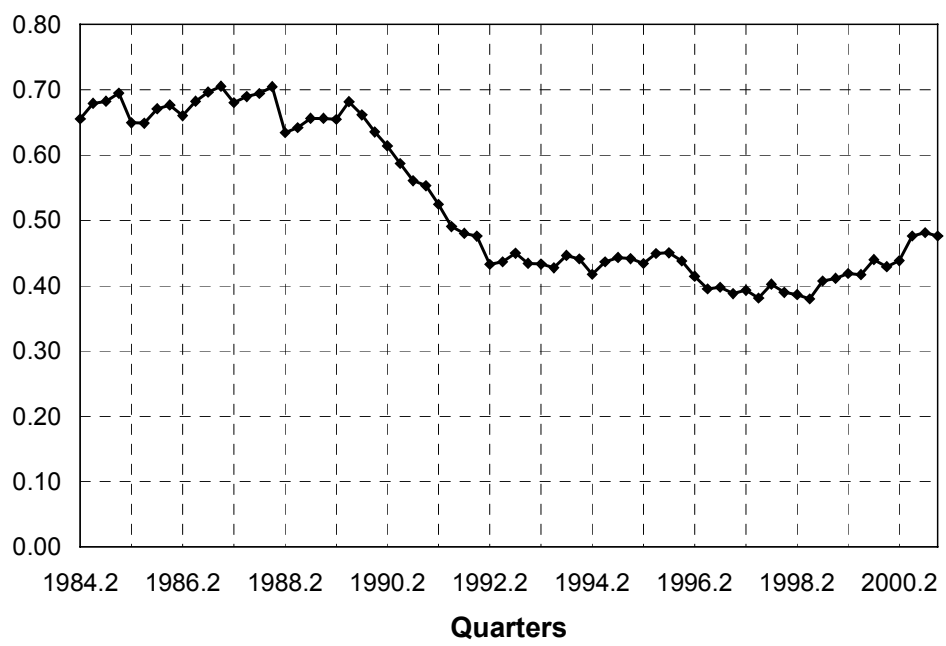


In contrast, the U.S. ratio for nonfinancial corporations is much lower, less than 0.2 , according to the Flow of Funds Accounts compiled by the Board of Governors. For some reason the ratio was high in the early $1980 \mathrm{~s} .{ }^{12}$ It is clear from this and previous figure that small firms during the "bubble" period used the cash and bank loans for financial investments. Second, turning to the mid to late 1990s, Figure 10 indicates that small firms relied on cash and deposits as a buffer against the steep decline in bank loans.

\subsection{Evidence from Cross-Section Regressions}

In the early 1990s, there was an active debate in the United States about whether the recession in that period was due to a credit crunch. To answer this question, Bernanke and Lown (1991) examined evidence from the U.S. states on output and loan growth. Based on a variety of evidence, including a cross-section regression involving output and loan growth by state, they concluded that the answer is probably no. In this subsection, we estimate the same type of regression for the 47 Japanese prefectures.

For the recession period of 1990-91, Bernanke and Lown (1991) find that employment growth in each state is related to contemporaneous growth in bank loans, with the bank loan regression coefficient of 0.207 with a $t$ value of over 3 . A positive coefficient in the regression admits two interpretations. The first is the "credit crunch" hypothesis that an exogenous decline in loan supply constrains investment and hence output. The second is that the observed decline in bank loans is due to a shift in loan demand. Bernanke and Lown (1991) prefer the second interpretation because the positive coefficient became insignificant when loan growth is instrumented by the capital ratio.

For Japan, we have available GDP by prefecture for fiscal years (April to March of the

\footnotetext{
${ }^{12}$ Some of the cash and deposits must be compensating balances. We do not have statistics on compensating balances, however.
} 
following year) and loan balance (to all firms and also to small firms whose paid-in capital is 100 million yen or less) at the end of March of each year $\frac{13}{13}$ The regression we run across prefectures is

$$
\text { GDP growth rate }=\beta_{0}+\beta_{1} \cdot \text { bank loan growth rate }
$$

According to the official dating of business cycles (published by the ESRI (Economic and Social Research Institute of the Cabinet Office of the Japanese government), there were five recessions since 1975: from March 1977 to October 1977, from February 1980 to February 1983, from June 1985 to November 1986, from February 1991 to October 1993, and from March 1997 to April 1999. Without monthly data, it is not possible to align these dates with our data on GDP and bank loans. We therefore focus on the three longer recessions.

Our results are reported in Table V. In the regression for 1996-98, for example, the dependent variable is GDP growth from fiscal year 1996 (April 1996 - March 1997) to fiscal year 1998 (April 1998 - March 1999).

Table V: Cross-Section Regression of GDP Growth on Loan Growth

\begin{tabular}{|c|c|c|}
\hline & Regression 1 & Regression 2 \\
\hline $\begin{array}{l}\text { Recession } \\
\text { years }\end{array}$ & $\begin{array}{l}\text { Independent variable is loan growth to all } \\
\text { firms from March to March over } \\
\text { indicated years }\end{array}$ & $\begin{array}{l}\text { Independent variable is loan growth to } \\
\text { small firms from March to March over } \\
\text { indicated years }\end{array}$ \\
\hline $1979-1982$ & $0.046(0.3)$ & $0.125(0.9)$ \\
\hline $1990-1993$ & $0.090(1.0)$ & $0.049(0.6)$ \\
\hline $1996-1998$ & $0.125(2.0)$ & $0.120(1.7)$ \\
\hline
\end{tabular}

Note: $t$ values in parentheses. The dependent variable is GDP growth rate over indicated fiscal years. The coefficient on the constant in the regression is not reported.

\footnotetext{
${ }^{13}$ See the Data Appendix for more details.
} 
This GDP growth is paired with the growth in loan balance from March 1996 to March 1998. The loan growth is for all firms in Regression 1 and for small firms in Regression 2. Regression 1 is comparable to the state-level regression in Bernanke and Lown (1991) for the U.S. states, except that the measure of output growth here is GDP growth, not employment growth. 15 Overall, the loan growth coefficient is not significant, which is consistent with our view that there may have been a credit crunch but it didn't matter for investment because firms found other ways to finance investment.

The significant coefficient for 1996-98 suggests that the recession in the late 1990s was partly due to a credit crunch, but this period is special. The three-month commercial paper rate, which has been about 0.5 to 0.6 percent since January 1996, shot up to above 1 percent in December 1997 and stayed near or above 1 percent before coming down to the 0.5 to 0.6 percent range in April 1998. During this brief period, various surveys of firms (for example, the Bank of Japan's survey called Tankan Survey) report a sharp rise in the fraction of small firms that said it was difficult to borrow from banks. The regression result in Table V, which detects a significant association between output and bank loans for 1996-98 but not for other periods, gives us confidence that the "credit crunch" hypothesis, while possibly relevant for output for a few

${ }^{14}$ If the loan growth from March 1997 to March 1999 is used instead, the $t$ value on loan growth is much smaller.

${ }^{15}$ Published data on employment by prefecture are available for Japan, but only for manufacturing and at the ends of calendar years. When we replaced GDP growth by employment growth in the regression, the loan growth coefficient was less significant. For example, if employment growth from December 1996 to December 1998 replaces the GDP growth from 1996-98, the $t$ value on the loan growth coefficient is 0.35 . Furthermore, in this employment growth equation, if the loan growth is for manufacturing firms, the loan growth coefficient is negative and insignificant. 
months from late 1997 to early 1998, cannot account for the decade-long stagnation. $\frac{16}{6}$

\section{Concluding Comments}

In examining the virtual stagnation that Japan began experiencing in the early 1990s, we find that the problem is not a breakdown of the financial system, as corporations large and small were able to find financing for investments. There is no evidence of profitable investment opportunities not being exploited due to lack of access to capital markets. Those projects that are funded are on average receiving a low rate of return.

The problem is low productivity growth. If it remains lower in Japan than in the other advanced industrial countries, Japan will fall further behind. We are not predicting that this will happen and would not be surprised if Japanese productivity growth returned to its level in the 1984-89 period. We do think that research effort should be focused on determining what policy reform will allow productivity to again grow rapidly.

We can only conjecture on what reforms are needed. Perhaps the low productivity growth is the result of a policy that subsidizes inefficient firms and declining industries. This policy results in lower productivity because the inefficient producers produce a greater share of the output. This also discourages investments that increase productivity. Some empirical support for this subsidizing hypothesis is provided by the experience of the Japanese economy in the 1978-83 period. During that five-year period that the 1978 "Temporary Measures for Stabilization of Specific Depressed Industries" law was in effect (see Peck, et al., 1988), the TFP growth rate was a dismal 0.64 percent. In the three years prior, the TFP growth averaged 2.18

\footnotetext{
${ }^{16}$ Our view that the "credit crunch" hypothesis is applicable only for the brief period of late 1997 through early 1998 is in accord with the general conclusion of the literature cited in footnote 1 , particulary Woo (1999) and Motonishi and Yoshikawa (1999).
} 
percent and in 6-year period after, it averaged slightly over 2.5 percent.

We said very little about the "bubble" period of the late 1980s and early 1990s, a boom period when property prices soared, investment as a fraction of GDP was unusually high, and output grew faster than in any other years in the 1980s and 1990s. We think the unusual pickup in economic activities, particularly investment, was due to an anticipation of higher productivity growth that never materialized. To account for the bubble period along these lines, we need to have a model where productivity is stochastic and where agents receive an indicator of future productivity. But the account of the lost decade by such a model would be essentially the same as the deterministic model used in this paper. 


\section{References}

Bayoumi, T. (1999), "The Morning After: Explaining the Slowdown in Japanese Growth in the 1990s," Journal of International Economics; 53, April 2001, 241-59.

Bernanke, B. and C. Lown (1991), “The Credit Crunch,” BPEA, 205-239.

Hansen, G., D. (1985), "Indivisible Labor and the Business Cycle," Journal of Monetary Economics, 16, 309-27.

Hayashi, F. (1997), Understanding Savings: Evidence from the United States and Japan, Cambridge: MIT Press.

Hoshi, T. and A. Kashyap (1999), “The Japanese Banking Crisis: Where Did It Come From and How Will It End?” NBER Macro Annual, 129-201.

Kashyap, A. and J. Stein (1994), "Monetary Policy and Bank Lending," in G. Mankiw, ed., Monetary Policy. Studies in Business Cycles, vol. 29. Chicago and London: University of Chicago Press, 1994, 221-56.

Kwon, E. (1998), "Monetary Policy, Land Prices, and Collateral Effects on Economic Fluctuations: Evidence from Japan," Jour. of Japanese and International Economies, 12, 175-203.

Motonishi, T. and H. Yoshikawa (1999), "Causes of the Long Stagnation of Japan during the 1990s, ” Jour. of Japanese and International Economies, 181-200.

Ogawa, K. and K. Suzuki (1998), "Land Value and Corporate Investment: Evidence from Japanese Panel Data, ” Jour. of Japanese and International Economies, 232-249.

Ogawa, K. and S. Kitasaka (1998), Asset Markets and Business Cycles (in Japanese), Nihon 
Keizai Shinbunsha.

Peck, M. J., R. C. Levin, and A. Goto (1988), "Picking Losers: Public Policy Toward Declining Industries in Japan," in Government Policy Towards Industry in the United States and Japan, J. B. Shoven, ed., Cambridge: Cambridge University Press, 165-239.

Rogerson, R. (1988), “Indivisible Labor Lotteries and Equilibrium,” Journal of Monetary Economics, 21, 3-16.

Sasaki, Y. (2000), "Prudential Policy for Private Financial Institutions," mimeo, Japanese Postal Savings Research Institute.

Woo, D. (1999), “In Search of 'Capital Crunch': Supply Factors behind the Credit Slowdown in Japan,” IMF Working Paper No. 99/3. 


\section{Data Appendix}

This appendix is divided into two parts. In the first part, we describe in detail how we constructed the model variables used in our neoclassical growth model. The second part describes how the data underlying the tables and figures in the text are constructed. All the data are in Excel files downloadable from http://www.e.u-tokyo.ac.jp/ hayashi/hp.

\section{Part 1. Construction of Model Variables}

The construction can be divided into two steps. The first is to make adjustments to the data from the Japanese National Accounts, which is our primary data source, to make them consistent with our theory. The second step is to calculate model variables from the adjusted national accounts data and other sources. The exact formulas of these steps can be found in the Excel file "rbc.xls" downloadable from the URL mentioned above.

\section{Step 1: Adjustment to the National Accounts}

Various adjustments to the Japanese National Accounts are needed for three reasons. First, depreciation in the Japanese National Accounts is on historical cost basis. Second, in our theory all government purchases are expensed. Third, starting in 2001 the Japanese National Accounts (compiled by the ESRI (Economic and Social Research Institute, Cabinet Office of the Japanese government)) adopted a new standard (called the 1993 SNA (System of National Accounts) standard) that is different from the previous standard (the 1968 SNA).

Extension to 1999 and 2000. For years up to 1998, the 2000 Annual Report on National Accounts has consistent series under the 1968 SNA standard. The 2001 Annual Report, which adopted the 1993 SNA standard, has series only for 1991-1999. The ESRI also releases series on the 1968 SNA basis for years up to 2000, but those series are only for a subset of the variables forming the income and product accounts. Furthermore, those accounts divide the whole economy into subsectors in a way different from the sector division in the 2000 Annual Report. From these three sources, it is possible, under the usual sort of interpolation and extrapolation, to construct consistent series for all relevant variables under the 1968 SNA standard up to 2000 (consult the Excel file mentioned above for more details). On the left side of Table A-I, we report values (relative to GNP) of items in the income and product accounts thus extended to 2000, averaged over 1984-2000. Also reported are capital stocks relative to GNP. Beginning-of-year (end-of-previous year) capital stocks for years up to 1999 are directly available from the 2000 Annual Report; capital stocks at the beginning of 2000 are taken from the 2001 Annual Report.

Capital consumption adjustments. The Japanese National Accounts include the balance sheets as well as the income and product accounts for the subsectors of the economy. In the income and product accounts, depreciation (capital consumption) is on historical cost basis, while in the balance sheets, capital stocks are valued at replacement costs. As was pointed out in Chapter 11 of Hayashi (1997), replacement cost depreciation implicit in the balance sheets can be estimated -- under a certain set of assumptions -- from various accounts included in the National Accounts. For years up to 1998, this Hayashi estimation of replacement cost depreciation is possible from the 2000 Annual Report, which conforms to the 1968 SNA standard and which includes data for years up to 1998. The procedure is in the Excel file "japsave.xls", downloadable from the URL mentioned above. The 2001 Annual Report, which adopted the 1993 SNA standard, actually reports replacement cost depreciation in its balance sheet section for 1991-1999. However, since the class of assets in the new SNA is broader, we use only the 1999 value and use it only to obtain our estimate of the 1999 value from the 1998 Hayashi estimate. For 2000, we linearly extrapolate from the 1998 and 1999 numbers. Consult the Excel file "rbc.xls" mentioned above for more details. From the estimate of replacement cost depreciation, an 
estimate of capital consumption adjustment can be obtained as the difference between the replacement cost depreciation thus calculated and the historical cost depreciation reported in the National Accounts. We use this capital consumption adjustment to make the National Account variables consistent with replacement cost accounting. For example, we add this capital consumption adjustment to (book value) depreciation to obtain depreciation at replacement costs, and we subtract the capital consumption adjustment from operating surplus.

Treatment of Government Capital. In our theory, all government purchases are expensed. Consequently, government consumption in the product account includes government investment, and capital consumption on government capital is subtracted from GNP to define (adjusted) GNP.

These two adjustments, capital consumption adjustments and expensing of government investment, are shown on the right side of Table A-I, where we provide descriptions of the adjustments and the adjusted values (relative to the unadjusted GNP).

\section{Step 2: Calculation of Model Variables from the Adjusted National Accounts}

The variables of our model are the following:

$W$ (wage income), $R$ (capital income), DEP (depreciation), $Y$ (adjusted GNP, exclusive of capital consumption on government capital), $C$ (private consumption), $X$ (investment, domestic investment plus investment in foreign assets), $G$ (government consumption), $K$ (capital stock), $h$ (hours worked per employed person), $E$ (number of employed persons), $N$ (working age population), and taxes on capital income.

Of these, $W, R$, and $D E P$ are used to calculate the capital income share $\theta$ as described in Section 3.2 of the text.

Income and Product Account Variables. Table A-II explains how the variables comprising the income and product accounts are constructed exclusively from the adjusted National Accounts. Imputed rent, which is the housing component of operating surplus in the noncorporate sector, is included in capital income. We assume that 80 percent of operating surplus in the nonhousing component of the noncorporate sector is wages. We need to divide indirect taxes between wages and capital income. For lack of good alternatives, we simply split it in half. Statistical discrepancy is allocated proportionately between $W, R$, and $D E P$. Thus, by construction, the sum of $W, R$, and $D E P$ equals $Y$ (GNP exclusive of capital consumption on government capital).

Capital stock, $\boldsymbol{K}$. Capital stock excludes government capital but includes capital in foreign countries. Capital in Foreign Countries $(K F)$ was calculated in the following way: $K F(1989)=25 *$ Net Factor Payments(1989), $K F(t+1)=K F(t)+\operatorname{Net} \operatorname{Exports}(t)+\operatorname{Net}$ Factor Payments $(t)$.

Average hours worked, $\boldsymbol{h}$. This variable is from an establishment survey conducted by the Ministry of Welfare and Labor (this survey is called Maitsuki Kinro Tokei Chosa). We use a series, included in this survey, for establishments with 30 or more employees. (There is a series for establishments with 5 or more employees, but this series is available only since 1990.)

Employment, $\boldsymbol{E}$. The number of employed persons for1970-98 is available from the National Accounts (see Table I-[3]-3 of the 2000 Annual Report on National Accounts). The Labor Force Survey (compiled by the General Affairs Agency) provides a different estimate of employment from 1960 to the present. To extend the estimate in the NIA back to 1960, we multiply the Labor Force Survey series by the ratio of the National Accounts estimate to the Labor Force Survey estimate for 1970.

Working-age Population, $\boldsymbol{N}$. The working-age population is defined as the number of people 
between ages 20 and 69 .

Taxes on Capital Income. This variable is used to calculate the tax rate on capital income, denoted $\tau$ in the text. It is defined as the sum of direct taxes on corporate income (available from the income account for the corporate sector in the National Accounts), 50 percent of indirect business taxes, and 8 percent of operating surplus in the nonhousing component of the noncorporate sector.

\section{Part 2. Data Underlying Tables and Figures}

Figures 1-5 and Table I use the model variables described in Part 1 of this appendix. Figures 6-8 are based on the simulation described in Section 3 of the text. The underlying data are in Excel file "rbc.xls".

Figure 9. Data on investment and bank loans are from the capital transactions account for nonfinancial corporations in the Japanese National Accounts (Table 1-[2]-III-1). For 1984-98, the data are from the 2000 Report on National Accounts, and the GNP used to deflate investment and bank loans are constructed as in Part 1 of this appendix. For 1999, the data are from the 2001 Report on National Accounts. The GNP for 1999 used to deflate is directly from this report. This is because the definition of investment in the 2001 report is based on the 1993 SNA definition. The data underlying this figure and Table III are in Excel file "nonfinancial.xls" downloadable from the URL already mentioned.

Table III. This too is calculated from the capital transactions account for nonfinancial corporations, available from the 2000 Report (for data for 1984-1998) and the 2001 Report (for 1999). Investment (excluding inventory investment), gross saving (defined as net saving plus depreciation), bank loans, and sale of land are directly available from the capital transactions account. Net increase in other liabilities is defined as investment less the sum of bank loans, sale of land, and gross saving. So the net increase in other liabilities, bank loans, sale of land, and gross saving add up to investment.

Figure 10. The data source is Hojin Kigyo Tokei (Incorporated Enterprise Statistics) collected by the MOF (Ministry of Finance). It is a large sample (about 18 thousand) of corporations from the population of about 1.2 million (as of the first quarter of 2000) listed and unlisted corporations excluding only very tiny firms (those with less than 10 million yen in paid-in capital). In the second quarter of each year, a freshly drawn sample of firms report quarterly income and balance-sheet items for four consecutive quarters comprising the fiscal year (from the second quarter of the year to the first quarter of the next year). The sampling ratio depends on firm sizes, with a 100 percent sampling of all "large" firms (about 5,400 firms, as of fiscal year 2000) whose paid-in capital is 1 billion yen or more. The MOF publishes sample averages by firm size. The sample averages we use are for "small" firms whose paid-in capital is less than 1 billion yen. For each fiscal year (April of the calendar year to March of the following year), investment for the fiscal year is the sum over the four quarters of the fiscal year of the sample average of investment (excluding inventory investment). The net increase in bank loans for fiscal year $t$ is the difference in the loan balance (defined as the sum of short-term and long-term borrowings from financial institutions) between the end of fiscal year $t$ (i.e., the end of the first quarter of calendar year $t+1$ ) and the end of the previous fiscal year (i.e., the end of the first quarter of calendar year $t$ ). Information on the balance sheet at the end of the previous fiscal year is available because the MOF collects this information for the firms newly sampled in the second quarter of year $t$. The GNP used to deflate is constructed as described in Part 1 of this appendix. The data underlying this figure, Table IV, and Figure 11 are in Excel file "mof.xls" downloadable from the URL already mentioned.

Table IV. The MOF survey is the source of this table also. Calculation of investment and bank loans is already described above for Figure 10. Sale of land for fiscal year $t$ is the difference in the book value of land between the end of fiscal year $t$ and the end of the previous fiscal year. The value for "other" is calculated as investment less the sum of bank loans and sale of land. 
Figure 11. This too is calculated from the MOF survey. It is the ratio of the sample average of cash and deposits for the small firms to the corresponding sample average of the book value of fixed assets (excluding land) at the end of each quarter.

Table V. Data on prefectural GDP for fiscal years are available from the Report on Prefectural Accounts (various years) published by the ESRI. Loan balance for domestically chartered banks by prefecture at the end of each March is available from A Survey on Domestically Chartered Bank Lending by Prefecture and by Client Firm's Industry by the Statistics Department of the Bank of Japan. The underlying data are in "prefecture.xls" downloadable from the URL already mentioned. 
Table A-I: National Income Accounts Adjustments

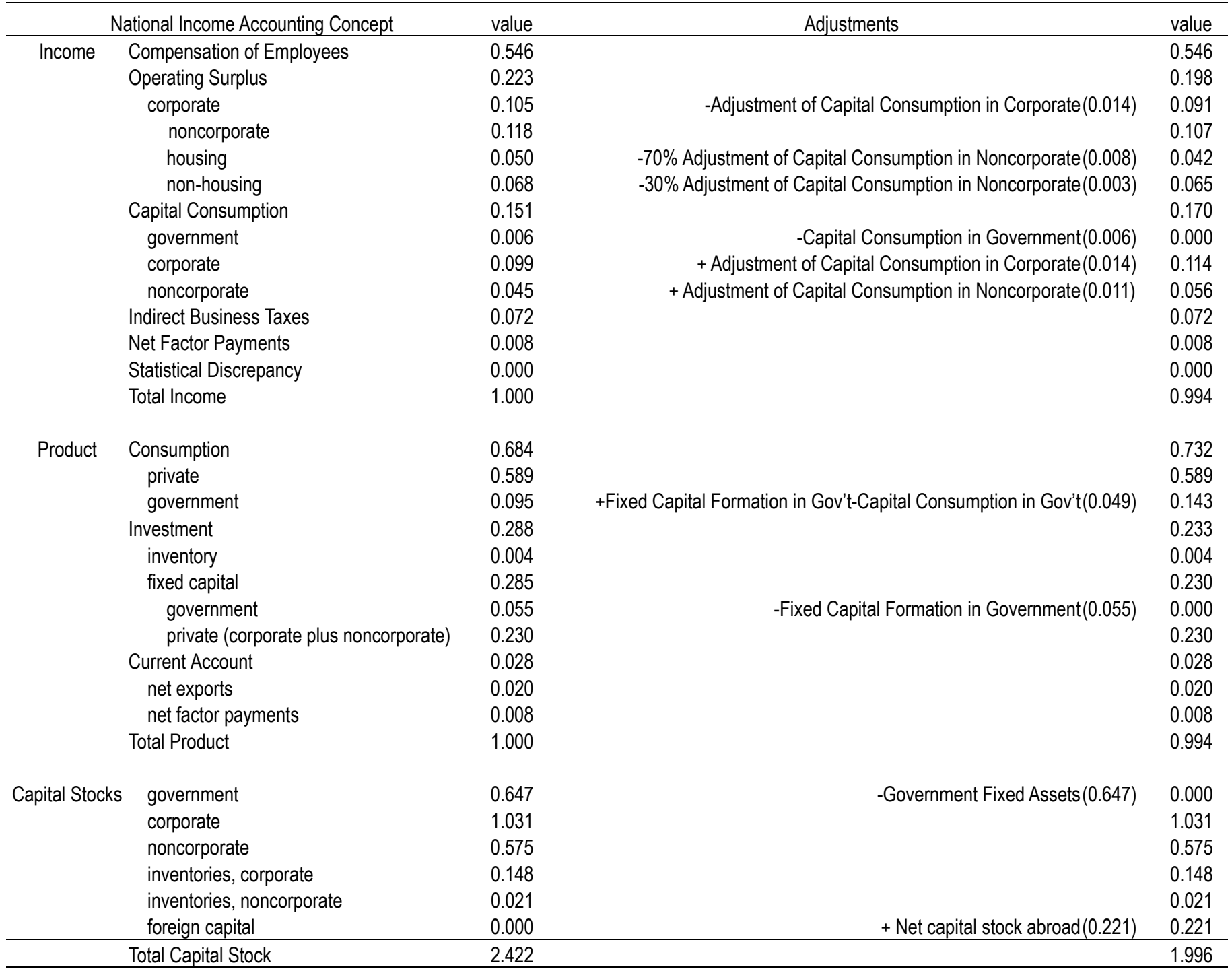

Note: averages of ratios to unadjusted GNP over 1984-2000. 
Table A-II: Model Variables and Relation to Adjusted NIA Data

\begin{tabular}{|c|c|c|}
\hline Variable & Name & Components \\
\hline $\boldsymbol{W}$ & Wage Income & $\begin{array}{l}\text { Compensation of Employees }+ \\
0.8 * \text { Operating Surplus in Non-housing Non-corporate Sector }+ \\
0.5 * \text { Indirect Business Taxes }+ \\
\text { Proportion of Statistical Discrepancy }\end{array}$ \\
\hline $\boldsymbol{R}$ & Capital Income & $\begin{array}{l}\text { Operating Surplus in Corporate Sector }+ \\
\text { Operating Surplus in Housing Non-corporate Sector }+ \\
0.2 * \text { Operating Surplus in Non-housing Non-corporate Sector }+ \\
0.5 * \text { Indirect Business Taxes }+ \\
\text { Proportion of Statistical Discrepancy }+ \\
\text { Net Factor Payments }\end{array}$ \\
\hline$D E P$ & Depreciation & $\begin{array}{l}\text { Total Capital Consumption (Corporate }+ \text { Non-corporate) }+ \\
\text { Proportion of Statistical Discrepancy }\end{array}$ \\
\hline $\boldsymbol{Y}$ & Income $=$ Output & $W+R+D E P=Y=C+G+X$ \\
\hline$C$ & Private Consumption & Private Consumption \\
\hline $\boldsymbol{G}$ & Gov't Expenditure & Adjusted Government Consumption \\
\hline$X$ & Investment & $\begin{array}{l}\text { Total Investment (Corporate }+ \text { Non-corporate })+ \\
\text { Net Exports }+ \\
\text { Net Factor Payments }\end{array}$ \\
\hline $\boldsymbol{K}$ & Capital Stock & $\begin{array}{l}\text { Total Capital Stock (Corporate }+ \text { Non-corporate }+ \\
\text { Stock of inventories) }+ \\
\text { Capital in Foreign Countries }\end{array}$ \\
\hline
\end{tabular}


